\title{
Seroprevalence of Leptospirosis in Dairy Cows with Reproductive Disorders
}

\author{
Alapa Baba Ikpe ${ }^{1}$, Kutubuddin Ahmed ${ }^{1}$, Dipak Kumar Sarma ${ }^{1}$, Durlav Prasad Bora ${ }^{2}$, Kalimuthusamy \\ Natarajaseenivasan ${ }^{3}$, Chandrani Goswami ${ }^{2}$ and Dhrubajyoti Borpujari ${ }^{*}$ \\ ${ }^{1}$ Department of Animal Reproduction, Gynaecology and Obstetrics, College of Veterinary Science, Assam Agricultural University, \\ Khanapara, Guwahati, Assam, INDIA \\ ${ }^{2}$ Department of Veterinary Microbiology, College of Veterinary Science, Assam Agricultural University, Khanapara, \\ Guwahati, Assam, INDIA \\ ${ }^{3}$ Department of Microbiology, Bharathidasan University, Tiruchirappalli, Tamil Nadu, INDIA \\ "Corresponding author: D Borpujari; E-mail:dr.borpujari@gmail.com
}

Received: 09 Aug., 2021

Revised: 05 Sept., 2021

Accepted: 08 Sept., 2021

\begin{abstract}
The present investigation was carried out to study the prevalence of leptospirosis in dairy cows with reproductive disorders in and around Kamrup district of Assam. A total of 130 sera collected from dairy cows with reproductive disorders in different localities of Assam were screened for leptospirosis by MAT. The seroprevalence of leptospirosis in dairy cows with reproductive disorders was found to be 14.62 per cent. Twelve Leptospira antigen serovars: L. Australis, L. Autumnalis, L. Ballum, L. Bataviae, L. Canicola, L. Grippotyphosa, L. Hebdomedis, L. Pomona, L. Pyrogenes, L. Sejroe, L. Icterohaemorrhagaie, and L. Javanica were used, to screen for leptospirosis. Leptospira antibodies were detected in four serovars: Australis, Autumnalis, Ballum and Bataviae. Australis was found to be the most circulating serovar with 47.37 per cent. The reproductive disorders reported in the present study were: repeat breeding 41 (31.54\%), abortion 34 (26.15\%), endometritis 25 (19.23\%), post-partum anoestrus $14(10.77 \%)$, dystocia $5(3.85 \%)$, retention of foetal membrane $4(3.07 \%)$, anovulation $2(1.53 \%)$, uterine prolapse 2 $(1.53 \%)$, silent oestrus $2(1.53 \%)$ and cystic ovaries $1(0.77 \%)$. Repeat breeding was found to be the most prevalent reproductive disorder (31.54\%) followed by cases of abortion (26.15\%) in different localities of Assam.
\end{abstract}

\section{HIGHLIGHTS}

(0 Australis, Autumnalis, Ballum and Bataviae serovars of Leptospira were found in dairy cattle in a flood affected areas of Assam (0 Leptospirosis was found to be common in dairy cows with history of abortion mostly during the third trimester.

Keywords: Incidence, Prevalence, Microscopic Agglutination Test, Abortion

Leptospirosis is a common global zoonotic disease in all warm-blooded animals, mostly in hot and humid areas. In India, Leptospirosis have been reported to be endemic in Southern states like Kerala, Tamil Nadu, Andhra Pradesh, Karnataka, and other coastal states like Gujarat, Maharashtra including Andaman and Nicobar Islands (Balamurugan et al., 2018). However, works on prevalence of leptospirosis in animals in North Eastern states of India are very scanty. Among the specific causes of reproductive disorders Leptospirosis is a well-known cause of reproductive losses in cattle including abortion, infertility still birth etc. (Mughini grass et al., 2014)
Typically, the disease occurs through bacterial exposure to mucous membranes and generally results in occult form or relatively mild acute clinical signs (Anwar et al., 2013). Leptospira infection had been reported as a source of great economic losses in dairy farms causing reproductive problems (Ijaz et al., 2018).

How to cite this article: Ikpe, A.B., Ahmed, K., Sarma, D.K., Bora, D.P., Natarajaseenivasan, K., Goswami, C. and Borpujari, D. (2021) Seroprevalence of Leptospirosis in Dairy Cows with Reproductive Disorders. J. Anim. Res., 11(05): 801-805.

Source of Support: None; Conflict of Interest: None क्) 
Bearing in mind that leptospirosis is a zoonotic disease and common to all warm-blooded mammals and the fact that, its presence had been established in other species, but no systematic study has been carried out in this region regarding bovine leptospirosis. Further, no work has so far been conducted on leptospirosis on animals with reproductive disorders. Hence, the findings of the present study would provide a baseline data on leptospirosis in cows with reproductive disorders.

\section{MATERIALS AND METHODS}

All work in the present study was conducted with the formal approval of Institutional animal ethics committee, Assam Agricultural University, Khanapara, Guwahati-781022 bearing the approval number $770 / \mathrm{GO} / \mathrm{Re} / \mathrm{S} / 03 / \mathrm{CPCSEA} /$ FVSc/AAU/IAEC/18-19/635dated 28.12.2018. A total of 130 crossbred cows, after clinicogynaecological examination and with history of reproductive disorders were selected from different localities in and around Kamrup district of Assam (Fig. 1). Kamrup district is situated between 25.46 and 26.49 North latitude and between 90.48 and 91.50 east latitude in a sub-tropical climatic condition with semi dry in summer and cold in winter. The district is separated into north and south part by the mighty river Brahmaputra. Due to heavy flood (almost $1 / 3 \mathrm{rd}$ of the district) during rainy season the livestock population is badly affected in this region. Blood samples were collected aseptically by vein puncture from the jugular vein in clot activator vial as shown in the Fig. 1 and the sera were separated by centrifugation which were stored at $-20^{\circ} \mathrm{C}$ till when Microscopic Agglutination Test (MAT) was carried out to study the seroprevalence of leptospirosis in dairy

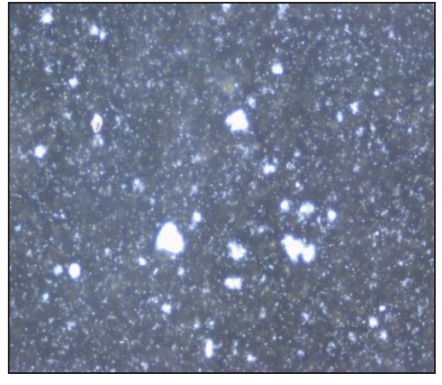

(a)

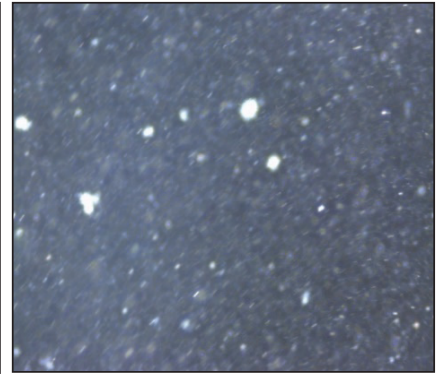

(b)

cows. Serum samples were later screened against twelve Leptospira antigen serovars: L. Australis, L. Autumnalis, L. Ballum, L. Bataviae, L. Canicola, L. Grippotyphosa, L. Hebdomedis, L. Pomona, L. Pyrogenes, L. Sejroe, L. Icterohaemorrhagaie, and L. Javanica as shown in the Fig 3 at a titre of 1:20 and highest dilution being 1:160 for leptospirosis by Microscopic Agglutination Test (MAT), following the standard procedure (W.H.O 2011; OIE, 2013).

The test samples were examined under the dark field microscope (Leica DM750) with camera (Leica MC190 HD) manufactured by Leica Microsystems (Schweiz) AG Industry Division CH-9435 Heerbrugg. The slides were observed under $20 \mathrm{X}$ objective, without coverslip for agglutination. The highest dilution (the one that gives $50 \%$ agglutination, leaving $50 \%$ of the cells free) was checked and then compared with a control suspension of leptospires diluted in PBS without serum.

Data were analyzed using Microsoft Excel (Microsoft Office 2007, Microsoft corporation, Redmond, Washington, USA).

\section{RESULTS AND DISCUSSION}

\section{Incidence of reproductive disorders in dairy Cows}

Out of a total of 130 samples collected from dairy cows in the present study, the reproductive disorders repeat breeding 41 (31.54\%) being the highest, abortion $34(26.15 \%)$, endometritis $25(19.23 \%)$, post-partum anoestrus $14(10.77 \%)$, dystocia $5(3.85 \%)$, retention of foetal membrane $4(3.08 \%)$, anovulation $2(1.54 \%)$, silent

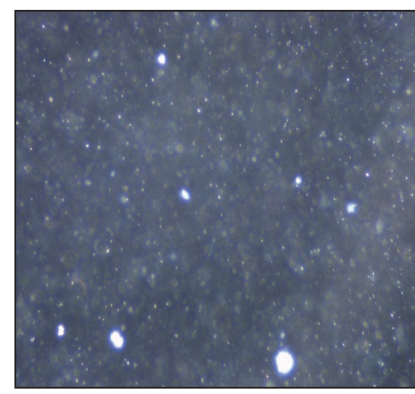

(c)

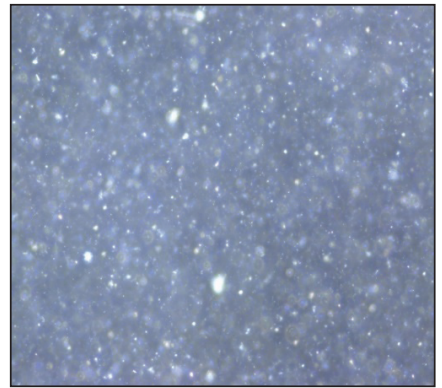

(d)

Fig. 1: (a) MAT titre at (1:20) (b) MAT titre at (1:40) (c) MAT titre at (1:80) (d) MAT titre at (1:160) 
oestrus $2(1.54 \%)$, uterine prolapse $2(1.54 \%)$ and cystic ovaries $1(0.77 \%)$.

This finding corresponds to work done by Ahmed et al. (1992) who reported cases of anoestrus, retained foetal membrane, endometritis, cervico-vaginal prolapse, uterine prolapse, dystocia and metritis in cattle in Assam. The present study was in agreement with the work of Dinka (2013), who recorded repeat breeding and abortion, (26.80 and 14.6 per cent respectively) as the major reproductive disorders of dairy cow. The result of the present study, differed from the work of Singh (2003) who recorded incidences of anoestrus, endometritis, retained foetal membrane, metritis, dystocia, abortion, cervicitis, prolapse, pyometra and stillbirth as $21.42,13.26,11.22$, $6.12,5.10,5.10,4.08,2.04,1.02$ and 1.02 per cent respectively in cattle in Assam. The result of his study showed a higher percentage of anoestrus $(21.42 \%)$ which could be due to breeds and management pattern. The present study differed with the work of Satyapal (2003), who reported incidences of abortion, stillbirth, dystocia, prolapse, retention of foetal membrane, and metritis in Karan Fries to be 7.85, 2.87, 3.05, 0.12, 27.65 and 29.70 per cent respectively.

\section{Seroprevalence of Leptospira infection in dairy cows} with history of reproductive disorders

In the present study, out of 130 dairy cows with history of reproductive disorders, the highest incidence of positive reactors was recorded in animal with history of abortion (35.29\%). The overall seroprevalence of leptospirosis in the study area was found to be 14.62 per cent and is presented in the Table 1.

Table 1: Seroprevalence of Leptospira infection in dairy cows with history of reproductive disorders

\begin{tabular}{llll}
\hline $\begin{array}{l}\text { Reproductive } \\
\text { disorders }\end{array}$ & $\begin{array}{l}\text { Total no. } \\
\text { of samples } \\
\text { tested }\end{array}$ & $\begin{array}{l}\text { No. of } \\
\text { Positive }\end{array}$ & $\begin{array}{l}\text { Prevalence } \\
\text { (\%) }\end{array}$ \\
\hline Abortion & 34 & 12 & 35.29 \\
$\begin{array}{l}\text { Repeat } \\
\text { breeding }\end{array}$ & 41 & 3 & 7.31 \\
$\begin{array}{l}\text { Endometritis } \\
\begin{array}{l}\text { Post-partum } \\
\text { anoestrus }\end{array}\end{array}$ & 25 & 2 & 8.00 \\
\hline
\end{tabular}

\begin{tabular}{llll}
$\begin{array}{l}\text { Silent oestrus } \\
\begin{array}{l}\text { Retention } \\
\text { of foetal }\end{array}\end{array}$ & 2 & - & - \\
membrane & 4 & 1 & 25 \\
$\begin{array}{l}\text { Uterine } \\
\text { prolapse }\end{array}$ & 2 & - & - \\
Anovulation & 2 & - & - \\
Cystic ovaries & 1 & - & - \\
Dystocia & 5 & - & - \\
\hline Total & $\mathbf{1 3 0}$ & $\mathbf{1 9}$ & $\mathbf{1 4 . 6 2}$ \\
\hline
\end{tabular}

Kader (2018), recorded 17.89 per cent seroprevalence of leptospirosis in cows in 10 districts of Assam. Malakar et al. (2016) reported 2.13 per cent seroprevalence of leptospirosis among human population. A higher seropositivity reported in the present study and Kader (2018) in cattle, might be due to regular exposure of animals and presence of prevailing risk factors in the farm premises.

The seroprevalence of leptospirosis in Assam might be said to be lower than the seroprevalence of leptospirosis in places like Andaman Islands where Sunder et al. (2016) reported 42.15 per cent (180/427) in cattle. Sharma et al. (2006) reported a high seroprevalence of leptospirosis in Andaman Islands recorded as 53.70 per cent (327/611) among human population. Sharma et al. (2014) reported a high seroprevalence of leptospirosis in cattle $(37.00 \%)$ and goat $(29.00 \%)$ in Andaman Islands compared to seroprevalence of leptospirosis of 14.62 per cent in the present study. Similar higher seroprevalence of 50.85 per cent in cattle with history of infertility, abortion and haemogalactia in Odisha and West Bengal states of Eastern India was reported by Behera et al. (2014).

\section{Seroprevalence of Leptospira serovars in dairy cows with reproductive disorders based on Microscopic Agglutination Test (MAT)}

Various serovars of Leptospira in dairy cows with different reproductive disorders were identified by MAT. Positive agglutination was seen as a glistering woolen ball appearance under the dark field microscope. This pattern indicated that the sera were specific to Leptospira serovars. The details of the Leptospira serovars identified through MAT and their seroprevalence are presented in Table 2. 
Table 2: Seroprevalence of Leptospira serovars in dairy cows with reproductive disorders based on MAT

\begin{tabular}{llll}
\hline $\begin{array}{l}\text { SI. } \\
\text { No. }\end{array}$ & Serovars & $\begin{array}{l}\text { No. of positive } \\
\text { serovars }\end{array}$ & $\begin{array}{l}\text { Prevalence } \\
(\%)\end{array}$ \\
\hline 1 & Australis & 9 & 47.37 \\
2 & Autumnalis & 6 & 31.58 \\
3 & Ballum & 2 & 10.53 \\
4 & Bataviae & 2 & 10.53 \\
5 & Canicola & - & - \\
6 & Grippotyphosa & - & - \\
7 & Hebdomedis & - & - \\
8 & Pomona & - & - \\
9 & Pyrogenes & - & - \\
10 & Sejroe & - & - \\
11 & Icterohaemorrhagiae & - & - \\
12 & Javanica & - & - \\
\hline & Total & $\mathbf{1 9}$ & $\mathbf{1 0 0}$ \\
\hline
\end{tabular}

Results showed that the most predominant serovars circulating in dairy cows with reproductive disorders in the study area were, L. Australis (47.37\%). The serum samples were tested for serovars specific antileptospiral antibodies, and were detected for their presence at different titre values of 1:20, 1:40, 1:80 and 1:160 as shown in Fig. 1 and the results have been presented in Table 3. A MAT titre ratio of 1:20 or above has been considered as standard (baseline dilution) for the positive reactor.

Table 3: Serovars specific antileptospire antibodies and their titre in seropositive dairy cows with reproductive disorders

\begin{tabular}{lllll}
\hline Serovar & $\mathbf{1 : 2 0}$ & $\mathbf{1 : 4 0}$ & $\mathbf{1 : 8 0}$ & $\mathbf{1 : 1 6 0}$ \\
\hline Australis & 9 & 7 & 2 & 1 \\
Autumnalis & 6 & 5 & 1 & - \\
Ballum & 2 & 1 & - & - \\
Bataviae & 2 & 1 & - & - \\
Canicola & - & - & - & - \\
Grippotyphosa & - & - & - & - \\
Hebdomedis & - & - & - & - \\
Pomona & - & - & - & - \\
Pyrogenes & - & - & - & - \\
Sejroe & - & - & - & - \\
Icterohaemorrhagiae & - & - & - & - \\
Javanica & - & - & - & - \\
\hline
\end{tabular}

Antibodies against Leptospira were detected in dairy cows with the history of abortion, repeat breeding, endometritis, post-partum, anoestrus and retained foetal membrane. The highest seroprevalence of leptospirosis (35.29\%) was recorded in dairy cattle with the history of abortion followed by retention of foetal membrane $(25.00 \%)$.

Antibodies against the serovars Australis, Autumnalis, Ballum and Bataviae were detected in dairy cows with reproductive disorders which corresponded to the report of Kader (2018), who recorded the serovars Autumnalis, Ballum, Bataviae and Javanica in cattle in 10 districts of Assam with low reproductive performance. This work was also in agreement with the work of Guitian et al. (2001), who reported suboptimal reproductive efficiency in Leptospira seropositive cattle in Galicia-Spain.

Seroprevalence of Leptospira infection in different stages of gestation in dairy cows with history of Abortion

Seroprevalence of Leptospira infection in dairy cows with history of abortion in different stages of gestation is shown in Table 4.

Table 4: Seroprevalence of Leptospira infection in different stages of gestation in dairy cows with history of abortion

\begin{tabular}{llll}
\hline Trimester & $\begin{array}{l}\text { No of samples } \\
\text { tested }\end{array}$ & Positive & $\begin{array}{l}\text { Prevalence } \\
\mathbf{( \% )}\end{array}$ \\
\hline First & 4 & 1 & 25 \\
Second & 5 & 1 & 20 \\
Third & 25 & 10 & 40 \\
\hline
\end{tabular}

Out of 34 cases of abortion, $12(35.29 \%)$ were positive for leptospirosis and out of 25 cows reported to have abortion at the third trimester, 10 (40\%) were positive for leptospirosis. The result of the present study revealed, that abortion due to leptospirosis occurred mostly in the third trimester of gestation. This finding was in agreement with that of earlier worker (Guitian et al., 2001) who reported late abortion, stillbirth and birth of weak calves in leptospirosis seropositive cows.

\section{CONCLUSION}

From the above study we can conclude that Australis, Autumnalis, Ballum and Bataviae serovars of Leptospira were found in dairy cattle and the Leptospirosis was found 
to be common in dairy cows with history of abortion mostly during the third trimester.

\section{ACKNOWLEDGEMENTS}

The authors thank the Dean, Faculty of Veterinary Science, AAU, Director of Research (Veterinary), AAU, Khanapara for providing necessary facilities to carry out this study. The financial support provided by DBT, India under North-East Twinning program on DBT-NER on "Seroprevalence of Leptospira infections in Animals of North East India" project (Grant No. BT/PR 16685/ $\mathrm{NE} / 95 / 249 / 2015)$ is also acknowledged.

\section{REFERENCES}

Adler, B. and de la Peña Moctezuma, A. 2010. Leptospira and leptospirosis. Vet. Microbiol., 140 (3-4): 287-296.

Ahmed, K., Deka, K.C., Deka, B.C. and Borgohain, B.N. 1992. Reproductive disorders in cattle in Assam. J. Assam Vet. Council, 2: 72-73.

Anwar, K., Khan, N. and Mujtaba, M. 2013. Seroprevalence of leptospirosis in aborted dairy cattle in Peshawar district suburb, Khyber Pakhtunkhwa Pakistan. Int. J. Curr. Microbiol. App. Sci., 2(8): 73-78.

Balamurugan, V., Sushma, R. A. T., Veena, S., Anusha, A., Nagalingam, M., Sridevi, R., Govindaraj, G., Hemadri, D.E., Gajendragad, M.R. and Rahman, H. 2016. Investigation on the distribution of Leptospira serovars and its prevalence in bovine in Konkan Region, Maharashtra, India. Adv. Anim. Vet. Sci., 4(2): 19-26.

Balamurugan, V., Alamuri, A., Bharathkumar, K., Patil, S. S., Govindaraj, G.N., Nagalingam, M., Krishnamoorty P., Rahman H and Shome, B.R. 2018. Prevalence of Leptospira serogroup-specific antibodies in cattle associated with reproductive problems in endemic states of India. Trop. Anim. Health Prod., 50(5): 1131-1138.

Behera, S.K., Sabarinath, T., Kumar, A., Das, S.C., Patra, D. and Chaudhuri, P. 2014. Seroprevalence of leptospirosis among suspected cattle in eastern part of India: a comparative study between rLipL32 ELISA and MAT. Ind J. Vet. Res., 15(3): 285-289.

Chandy, S., Kirubanandhan, L., Hemavathy, P., Khadeeja, A.M., Kurian, S.J., Venkataraman K., Mørch, K., Mathai, D. and Manoharan A. 2017. Serovar prevalence of Leptospira in semirural India and the development of an IgM-based indirect ELISA. J. Infect. Dev. Ctries., 11(3): 234-241.
Dinka, H. 2013. Major reproductive disorders of dairy cows in and around Asella town, Central Ethiopia. J. Vet. Med. Anim. Health., 5(4): 113-117.

Guitian, J., Garcia, P., Francisco, P., Oliveira, J.L., Sanju, M. and Yus, Ãn, E. 2001. Serological study of the frequency of Leptospiral infections among dairy cows in farms with suboptimal reproductive efficiency in Galicia, Spain. Vet. Microbiol., 80: 275-284.

Ijaz, M., Abbas, S.N., Farooqi, S.H., Aqib, A.I., Anwar, G.A., Rehman, A., Ali, M.M., Mehmood, K., and Khan, A. 2018. Sero-epidemiology and hemato-biochemical study of bovine leptospirosis in flood affected zone of Pakistan. Acta Tropica., 177: 51-57.

Kader, N.A. (2018). Seroprevalence and risk factors analysis of leptospirosis in cattle population of Assam. M.V.Sc. Thesis, Assam Agricultural University, Khanapara, Guwahati, Assam.

Malakar, M.S. Roy, F. and Pandey, K. 2016. Incidence of leptospirosis infections among acute febrile patients in Lakhimpur and Dhemaji districts, India. Int. J. Tropic. Dis. Health, 15 (3): 2278

Mughini-Gras, L., Bonfanti, L., Natale, A., Comin, A., Ferronato, A., La Greca, E., Patregnani, T., Lucchese, L. and Marangon, S. 2014. Application of an integrated outbreak management plan for the control of leptospirosis in dairy cattle herds. Epidemiol. Infect., 142(6): 1172-1181.

Satyapal. 2003. Investigation on health disorders in dairy cattle and buffaloes during pre and post-partum period. Ph.D. Thesis, NDRI, Karnal.

Sharma, S., Vijayachari, P., Sugunan, A.P., Roy, S. and Natarajaseenivasan, K. 2014. Seroprevalence and carrier status for leptospirosis in cattle and goats in Andaman Island, India. J. Vet. Sci. Technol., 5: 205.

Sharma, S, Vijayachari, P., Sugunan, A.P. Natarajaseenivasan, K. and Sehgal, S.C. 2006. Seroprevalence of leptospirosis among high-risk population of Andaman Islands. India. Am. J. Trop. Med. Hyg., 74(2): 278-283.

Singh, S.K. 2003. A comparative study on ovarian conditions and reproductive disorders in local and crossbred cattle of Assam. M.V.Sc. Thesis, Assam Agricultural University, Khanapara, Guwahati-22, Assam.

Sunder, J., Sujatha, T. and Kundu, M.S. 2016. Carrier status and seroprevalence of leptospirosis in cattle in South Andaman. Indian J. Anim. Res., pp. 0976-0555.

Vijayachari, P., Sugunan, A.P. and Shriram, A.N. 2008. Leptospirosis: an emerging global public health problem. $J$. Biosci., 33(4): 557-569. 
